\title{
The Isolation and Activity of Growth-Stimulating Factors from Human Platelets ${ }^{1}$ )
}

\author{
By B. Dresow and A. Delbrück \\ Institut für Klinische Chemie II der Medizinischen Hochschule Hannover, \\ Zentrallabor im Krankenhaus Oststadt, Hannover
}

(Received October 31, 1983/April 30, 1984)

Respectfully dedicated to Professor Dr. Dr. h.c. mult. Fritz Lipmann on the occassion of his 85th birthday

Summary: Optimal conditions for determining the mitogenic activity of platelet growth factor in a homologous system (human palmar fascia fibroblasts/human platelet growth factor) were established. With the aid of this system it was possible to test the active fraction from crude platelet extract following affinity chromatography on heparin-Sepharose, chromatofocusing and molecular sieve filtration. This fraction has an isoelectric point of $\mathrm{pH}>9$ with a molecular mass of about 12000 daltons and reacts with $\beta$-thromboglobulin antiserum. The addition of protease inhibitors proved essential for the isolation of the active growth factor, in order to prevent proteolytic degradation to a biologically inactive substance that is immunologically identical to $\beta$ thromboglobulin. In addition to stimulation of DNA synthesis, the isolated growth factor induces enhanced synthesis of collagen and glycosaminoglycans in fibroblasts in vitro.

\section{Zur Isolierung und Wirkung von wachstumsstimulierenden Faktoren aus menschlichen Thrombocyten}

Zusammenfassung: Optimale Bedingungen zur Bestimmung der proliferationsstimulierenden Aktivität von Thrombocytenwachstumsfaktor im homologen System (menschliche Fibroblasten aus Palmarfascie/menschlicher Thrombocytenwachstumsfaktor) wurden erarbeitet. Mit Hilfe des Testsystems konnte die aktive Fraktion aus dem Thrombocytenrohextrakt nach Affinitätschromatographie an Heparin-Sepharose, Chromatofokussierung und Molekularsiebtrennung erfaßt werden. Diese einheitliche Fraktion besitzt einen isoelektrischen Punkt von pH >9, weist eine molekulare Masse von etwa 12000 Dalton auf und reagiert mit Antiserum gègen $\beta$-Thromboglobulin. Wesentlich für die Isolierung des aktiven Wachstumsfaktors erwies sich der $\mathrm{Zu}-$ satz von Proteasehemmern, um den proteolytischen Abbau zu einer biologisch inaktiven Substanz zu verhindern. Diese ist mit $\beta$-Thromboglobulin immunologisch identisch. Neben einer Stimulation der DNA-Synthese induziert der isolierte Wachstumsfaktor eine Steigerung der Kollagen- sowie der Glykosaminoglykansynthese in Fibroblasten in vitro.

\section{Introduction}

The observation that serum, but not plasma, promotes the growth of fibroblasts in vitro (1) led to the discovery of various factors that stimulate cell growth (2). The major component of mitogenic activity in serum proved to be a factor originating from

') Supported by the Deutsche Forschungsgemeinschaft (Sonderforschungsbereich 54). the $\alpha$-granulas of platelets $(3,4)$. This factor exhibits strong mitogenic activity on fibroblasts, smooth muscle and synovial cells in culture (5). Various findings have been reported regarding growth stimulation of vascular endothelial cells $(6,7)$.

Possible roles of the platelet growth factor in wound healing, atherogenesis, and oncogenesis are under discussion (5). A link to the pathogenesis of rheumatoid arthritis has been provided by Mac Carter, 
Hossler \& Castor (8), who found that plasma from patients with rheumatoid arthritis or lupus erythematosus has higher levels of a connective-tissue stimulating factor derived from platelets than healthy controls (connective-tissue activating peptide III). Myers \& Christine (9) demonstrated elevated concentrations of this factor in the synovia of patients with inflammatory arthritic diseases. Weissbarth et al. (10) reported the induction of platelet release by sera from patients with rheumatoid arthritis.

It is difficult to make unambiguous statements, because the platelet growth factors described by several authors in the literature differ in structure and physical properties. Thus "platelet-derived growth factor" $(11,12,13)$ with a relative molecular mass of 27000-35000, "human platelet basic protein" (14) with a relative molecular mass of $10000-15000$, "connective-tissue activating peptide III" (15) and "low-affinity platelet factor 4" (16) both with a relative molecular mass of 9300 have all been described as platelet-derived factors with mitogenic activity. Immunologically, there is no distinction between platelet basic protein, connective-tissue activating peptide III/low affinity platelet factor 4 and the socalled packing protein of the platelets, $\beta$-thromboglobulin, which has no stimulatory activity. The objective of the work under review was to isolate the platelet growth factor or factors with simultaneous separation of immunologically identical but inactive factors, to obtain clues as to the identity of the various factors described in the literature, and to devise a test for proliferation stimulation, in order to determine mitogenic activity. A further aim was to ascertain the extent to which the proliferation-promoting effect is associated with metabolic stimulating properties.

\section{Materials and Methods \\ Crude platelet extract}

Fresh donor citrate blood $(100-500 \mathrm{ml})$ was centrifuged for 10 min at $100 \mathrm{~g}$. The supernatant was separated and centrifuged for $10 \mathrm{~min}$ at $1000 \mathrm{~g}$. The platelet sediment was washed twice, each time with a mixture consisting of 8 parts phosphate buffer $(0.1$ $\mathrm{mol} / 1 \mathrm{NaCl}, 2.68 \mathrm{mmol} / 1 \mathrm{KCl}, 6 \mathrm{mmol} / / \mathrm{Na}_{2} \mathrm{HPO}_{4} \times 2 \mathrm{H}_{2} \mathrm{O}, 4$ $\left.\mathrm{mmol} / \mathrm{KH} \mathrm{KHO}_{4}\right)$ and 2 parts citrate solution $(0.07 .6 \mathrm{~mol} / \mathrm{l}$ citric acid, $0.15 \mathrm{~mol} / \mathrm{/} \mathrm{Na}$-citrate) $\mathrm{pH} 6.8$ and centrifuged for $10 \mathrm{~min}$ at $1000 \mathrm{~g}$. The platelets were then suspended in $0.05 \mathrm{~mol} / \mathrm{h}$ tris buffer, containing $0.15 \mathrm{~mol} / \mathrm{l} \mathrm{NaCl}(\mathrm{pH} 7.8)$ and protêase inhibitors (0.1 mol/1 6-aminocaproic acid, $0.01 \mathrm{~mol} / 1 \mathrm{EDTA}, 5 \mathrm{mmol} / 1$ benzamidine hydrochloride hydrate, $0.3 \mathrm{mmol} / \mathrm{N}$-acetylcysteine). The cells were disrupted by means of fourfold deep-freezing and thawing, and the crude platelet extract was separated from cellular debris by centrifugation for $60 \mathrm{~min}$ at $5000 \mathrm{~g}$ and $4{ }^{\circ} \mathrm{C}$.

\section{Isolation of platelet growth factor}

The crude platelet extract was heated for $10 \mathrm{~min}$ at $100^{\circ} \mathrm{C}$. Precipitated protein was removed by centrifugation at $5000 \mathrm{~g}$, and the clear supernatant was fractionated on Sephadex $\mathbf{G} 75$ (column $75 \times 2.5 \mathrm{~cm}$, eluant: $0.05 \mathrm{~mol} / \mathrm{l}$ tris $-0.15 \mathrm{~mol} / / \mathrm{NaCl}, \mathrm{pH} 7.8$, elution speed $10 \mathrm{ml} / \mathrm{h}$ ) into molecular moieties greater than and smaller than 60000 dalton. The low-molecular portion was applied to a heparin-Sepharose column $(12 \times 1 \mathrm{~cm})$. After washing with $0.05 \mathrm{~mol} / \mathrm{h}$ tris $-0.15 \mathrm{~mol} / \mathrm{I} \mathrm{NaCl}, \mathrm{pH} 7.8$, the growth-stimulating fraction was eluted with $0.05 \mathrm{~mol} / \mathrm{tris}-0.5 \mathrm{~mol} / \mathrm{NaCl}$, $\mathrm{pH} 7.8$, dialysed against $0.05 \mathrm{~mol} / \mathrm{h}$ tris $-0.15 \mathrm{~mol} / \mathrm{NaCl}$, $\mathrm{pH} 7.8$, and again purified over heparin-Sepharose as above.

Isoelectric focusing for separation of platelet growth factors

The material purified over heparin-Sepharose was fractionated by chromatofocusing on PBE 94 (Pharmacia) polybuffer exchanger pH 9.4 (column: $25 \times 1 \mathrm{~cm}$ ) with polybuffer 96 (Pharmacia) pH 6.0 at an elution speed of $6 \mathrm{~mL} / \mathrm{h}$. For determining the mitogenic activity of the fractions $\mathrm{A}$ ( $\mathrm{pI}>9.0$ ), B (pI 8.9-7.6) and C (pI 7.5-6.5), these were again subjected to affinity chromatography on heparin-Sepharose, after which the purified fractions were used in the proliferation test.

\section{Molecular sieve separation of the factors}

Molecular sieve separation of the mitogenic fraction obtained after chromatofocusing was performed on a Sephadex $\mathrm{G} 75$ column $(120 \times 1.2 \mathrm{~cm}$, eluant: Dulbecco's phosphate buffer pH 7.0, elution speed $3.1 \mathrm{ml} / \mathrm{h}$ ). Calibrated proteins from Boehringer, Mannheim served as markers (cytochrome c: relative molecular mass 12500 , chymotrypsin: relative molecular mass 25000 , albumin from chicken eggs: relative molecular mass 45000 , ferritin: relative molecular mass 450000).

\section{Inhibition of proteolysis of platelet growth factor}

A crude platelet extract obtained by repeated freezing and thawing without the addition of protease inhibitors was separated into three portions (A, B, C). Portion. A was incubated for $2 \mathrm{~h}$ at $4{ }^{\circ} \mathrm{C}$, portion $\mathrm{B}$ for $2 \mathrm{~h}$ at $37^{\circ} \mathrm{C}$ and portion $\mathrm{C}$ for $2 \mathrm{~h}$ at $37^{\circ} \mathrm{C}$ with the addition of protease inhibitors (see above). Each solution was heated for $10 \mathrm{~min}$ to $100^{\circ} \mathrm{C}$ and centrifuged for $60 \mathrm{~min}$ at $5000 \mathrm{~g}$. Following affinity chromatography of the supernatant on heparinSepharose, mitogenic activity was determined in the proliferation test.

\section{$\beta$-Thromboglobulin radioimmunoassay}

The radioimmunoassay was performed with the IM $88 \beta$-thromboglobulin RIA kit (Amersham/Buchler).

\section{Cell count}

The cell numbers were determined $40 \mathrm{~h}$ after factor application as described previously (18).

\section{Proliferation test}

Mitogenic activity was determined on the basis of $\left[{ }^{3} \mathrm{H}\right]$ thymidine incorporation in human palmar fascia fibroblasts (18). The cells were preserved deep-frozen in the first to third subculture and seeded in plastic dishes for the test $\left(2 \mathrm{~cm}^{2}\right.$ culture surface). Culture medium: 89 parts Eagle's minimum essential medium (MEM) with Earl's saline solution, $2 \mathrm{mmol} / \mathrm{A}$ glutamine, 1 part vitamin concentrate (Flow Laboratories), $100 \mathrm{IU} / \mathrm{ml}(100 \mathrm{mg} / \mathrm{l})$ penicillin/streptomycin, and ten parts foetal calf serum (FCS). Atmosphere: 95 parts air, 5 parts $\mathrm{CO}_{2}$ at $37^{\circ} \mathrm{C}$. After $48 \mathrm{~h}$ the medium was sucked off, and the cell cultures were washed with $0.5 \mathrm{ml}$ of Dulbecco's phosphate buffer (PBS), $\mathrm{pH}$ 7.0. In four to eight 
replicate determinations, $0.3 \mathrm{ml}$ of a mixture consisting of 10 parts of the fraction to be tested (dialysed against PBS) or PBS as a control, 85 parts medium and 5 parts FCS were then added to the culture. After addition of $33 \mathrm{kBq}\left[{ }^{3} \mathrm{H}\right]$ thymidine (Amersham/ Buchler, D-3300 Braunschweig) in $0.2 \mathrm{ml}$ of medium, the culture was incubated for $24 \mathrm{~h}$, a time interval widely described for $\left[{ }^{3} \mathrm{H}\right]$ thymidine incorporation experiments into $3 \mathrm{~T} 3$ and glial cells $(14,15,19,20,21)$. Incubation was terminated by sucking off the test medium and adding ethanol. The cells were then digested as described in 1.c. (18). The incorporated activity was measured in a Packard Tricarb 2660 liquid scintillation counter.

\section{Optimization of the proliferation test}

Optimization of the proliferation-stimulation test was carried out as follows:

1) Reduction of the portion of foetal calf serum in the test medium from 5 to 3 to 1 part;

2) variation of the cell density of the cultures and

3) shifting the time at which the $\left[{ }^{3} \mathrm{H}\right]$ thymidine was added after the test substance.

Optimal test conditions were determined as follows: Inoculation of cells to a density of approx. 10000 cells $/ \mathrm{cm}^{2}$. After $48 \mathrm{~h}$, test sample added in MEM containing 1 part of foetal calf serum, and incubation continued for $15 \mathrm{~h}$. Addition of $\left[{ }^{3} \mathrm{H}\right]$ thymidine and further incubation for $24 \mathrm{~h}$. Determination of $\left[{ }^{3} \mathrm{H}\right]$ thymidine incorporation as described.

Determination of $\left[{ }^{35} \mathrm{~S}\right]$ sulphate and $\left[{ }^{3} \mathrm{H}\right]$ proline or $\left[{ }^{3} \mathrm{H}\right]$ hydroxyproline incorporation in vitro

Fibroblasts from human palmar fascia of the second and third subculture were seeded in $8 \mathrm{~cm}^{2}$ plastic culture dishes. After $24 \mathrm{~h}$, $50 \mu \mathrm{g}$ of ascorbate per $\mathrm{ml}$ of medium was added for determination of collagen synthesis. Forty eight hours after inoculation the medium was sucked off and the cell colonies were washed with phosphate buffer (PBS), pH 7.0. To the culture was then added $1.5 \mathrm{ml}$ of test mixture ( 89 parts medium, 1 part foetal calf serum, and either 10 parts of the fraction to be tested (dialysed against PBS)), or of PBS to act as a control. For determination of glycosaminoglycan synthesis sulphate-free medium had to be used. After an incubation period of $24 \mathrm{~h}, 121 \mathrm{kBq}$ of the tracer substance $\left[{ }^{3} \mathrm{H}\right]$ proline or $242 \mathrm{kBq}$ of $\left[{ }^{35} \mathrm{~S}\right]$ sulphate (Amersham/Buchler, D3300 Braunschweig) in $0.5 \mathrm{ml}$ medium was added and incubated for a further $48 \mathrm{~h}$. The incorporation rates of $\left[{ }^{3} \mathrm{H}\right]$ proline and $\left[{ }^{3} \mathrm{H}\right]$ hydroxyproline into collagen and $\left[{ }^{35} \mathrm{~S}\right]$ sulphate into glycosaminoglycans were determined as described in l.c. (18).

\section{Results}

A proliferation test, operating in a homologous system (human platelet factor/human palmar fascia fibroblasts), was developed for quantifying mitogenic activity. The effects were studied of varying the concentration of foetal calf serum (fig. 1), the cell density of the cultures (fig. 2), and the time at which the labeled precursor $\left[{ }^{3} \mathrm{H}\right]$ thymidine was added after the factor had begun to exert an effect on the cells (fig. 3). In this way, accelerated rates for $\left[{ }^{3} \mathrm{H}\right]$ thymidine incorporation of up to 20 times the control value were achieved. Replacement of foetal calf serum by human serum resulted in no further increase.

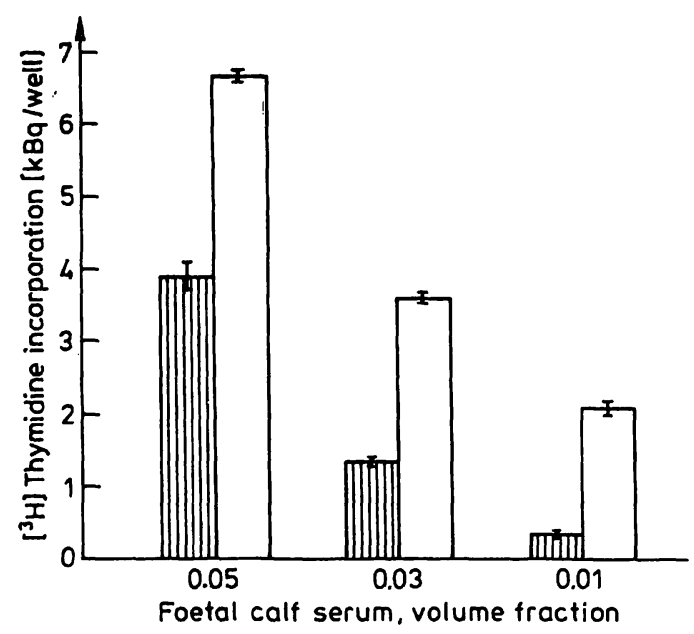

Fig. 1. Stimulation of $\left[{ }^{3} \mathrm{H}\right]$ thymidine incorporation by heparinSepharose purified platelet growth factor in dependence on the concentration of foetal calf serum (in volume fraction of foetal calf serum in the culture medium). Incorporation in $\mathrm{kBq}$ per culture well $\left(\mathrm{n}=8 ; 2 \mathrm{~cm}^{2}\right.$ surface, cell density about $40200 \mathrm{cells} / \mathrm{cm}^{2}, 2.1 \mu \mathrm{g} \beta$-thromboglobulin immunoreactive material per $\mathrm{ml}$ medium), the bars indicate the standard deviation.

鮞 control: buffer only

$\square$ sample with platelet growth factor

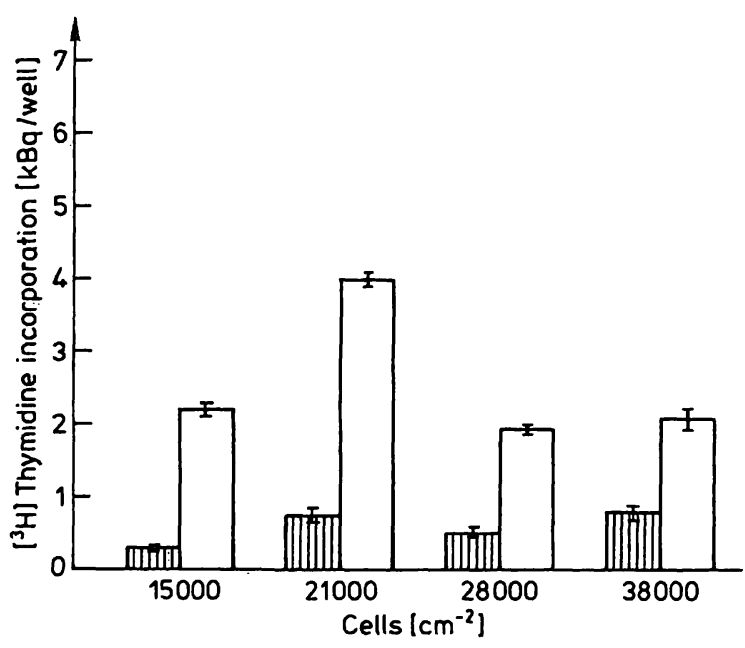

Fig. 2. Stimulation of $\left[{ }^{3} \mathrm{H}\right]$ thymidine incorporation by heparinSepharose purified platelet growth factor in dependence on the cell density of the culture. Incorporation in $\mathrm{kBq}$ per culture well $\left(\mathrm{n}=8 ; 2 \mathrm{~cm}^{2}\right.$ surface; volume fraction of foetal calf serum $0.01 ; 2.45 \mu \mathrm{g} \beta$-thromboglobulin immunoreactive material per $\mathrm{ml}$ medium), the bars indicate the standard deviation.

囵 control: buffer only

$\square$ sample with platelet growth factor

As shown in figure 4 this $\left[{ }^{3} \mathrm{H}\right]$ thymidine incorporation assay correlates well with the measurement of cell growth. The $\left[{ }^{3} \mathrm{H}\right]$ thymidine incorporation assay represents the more sensitive method. Sensitivity was $200 \mathrm{ng}$ of $\beta$-thromboglobulin immunoreactive material purified over heparin-Sepharose per $\mathrm{ml}$ of test medium. 


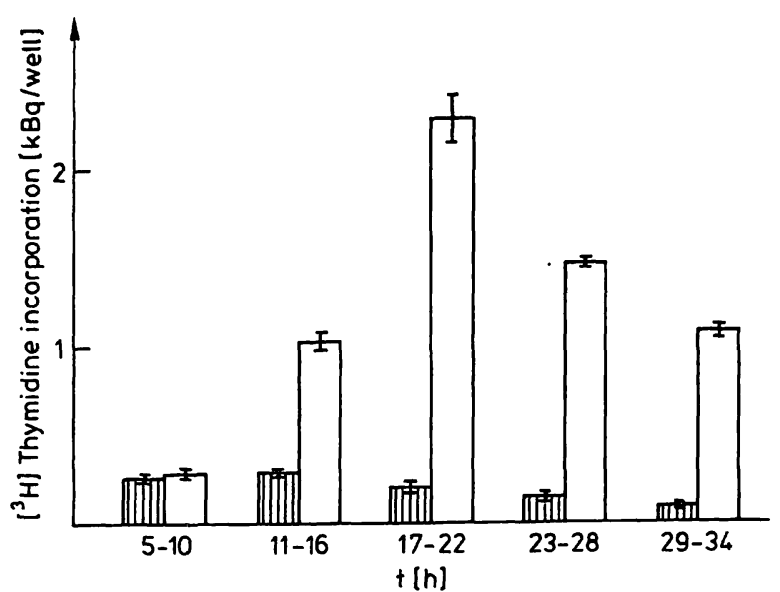

Fig. 3. Stimulation of $\left[{ }^{3} \mathrm{H}\right]$ thymidine incorporation by heparinSepharose purified platelet growth factor: Influence of the time interval between factor application and addition of the labeled precursor. Incorporation in $\mathrm{kBq}$ per culture well $\left(\mathrm{n}=6 ; 2 \mathrm{~cm}^{2}\right.$ surface; cell density about 17500 cells/ $\mathrm{cm}^{2}$; volume fraction of foetal calf serum $0.01 ; 8 \mu \mathrm{g} \beta$ thromboglobulin immunoreactive material per ml medium), the bars indicate the standard deviation.

Bi control: :buffer only

$\square$ sample with platelet growth factor

With the help of the proliferation test isolation of the platelet growth factor was pursued. By repeated deep-freezing and rethawing, using protease inhibitors and molecular sieve filtration followed by affinity chromatography on heparin-Sepharose, it was possible to obtain a platelet fraction from fresh citrate blood that had a high concentration of $\beta$-thromboglobulin immunoreactive material. This fraction exhibited marked mitogenic activity in the proliferation test (tab. 1). The addition of protease inhibitors proved essential for the preservation of the mitogenic activity of the preparation (fig. 5).

Tab. 1. Fractionation of crude platelet extract obtained from $2.3 \cdot 10^{10}$ platelets $(150 \mathrm{ml}$ blood $) .{ }^{*} \mathrm{H}$-incorporation $=$ stimulation of $\left[{ }^{3} \mathrm{H}\right]$ thymidine incorporation into DNA by human palmar fascia cells in $\mathrm{kBq}$ per culture well $\left(2 \mathrm{~cm}^{2}\right.$ surface; cell density 16800 cells $/ \mathrm{cm}^{2} ; 3.4 \mu$ g platelet protein per ml medium).

\begin{tabular}{|c|c|c|c|}
\hline Fractions & Protein & $\begin{array}{l}\beta- \\
\text { Throm- } \\
\text { bo- } \\
\text { globulin } \\
\mu \mathrm{g}\end{array}$ & $\begin{array}{l}{ }^{3} \mathrm{H} \text {-incorpora- } \\
\text { tion }\end{array}$ \\
\hline $\begin{array}{l}\text { Crude platelet extract (1) } \\
100^{\circ} \mathrm{C} / 100 \mathrm{~min} \text { (II) }\end{array}$ & $\begin{array}{l}5750 \\
1900\end{array}$ & $\begin{array}{l}191 \\
147\end{array}$ & $\begin{array}{l}\text { inhibition } \\
0.45 \mathrm{kBq}\end{array}$ \\
\hline \multicolumn{4}{|l|}{$\begin{array}{l}\text { Sephadex G } 75 \\
\text { chromatography }\end{array}$} \\
\hline $\begin{array}{l}M_{\mathrm{r}}>60000 \text { (III) } \\
M_{\mathrm{r}}<60000 \text { (IV) }\end{array}$ & $\begin{array}{l}970 \\
750\end{array}$ & $\begin{array}{l}0.6 \\
137\end{array}$ & $\begin{array}{l}\text { no activity } \\
\text { not determined }\end{array}$ \\
\hline \multicolumn{4}{|l|}{$\begin{array}{l}\text { Heparin-sepharose } \\
\text { chromatography of (IV) }\end{array}$} \\
\hline $\begin{array}{l}\text { not adsorbed (V) } \\
0.5 \mathrm{~mol} / 1 \mathrm{NaCl} \text { eluate }(\mathrm{VI})\end{array}$ & $\begin{array}{l}398 \\
205\end{array}$ & 119 & $\begin{array}{l}0.15 \mathrm{kBq} \\
2.81 \mathrm{kBq}\end{array}$ \\
\hline
\end{tabular}

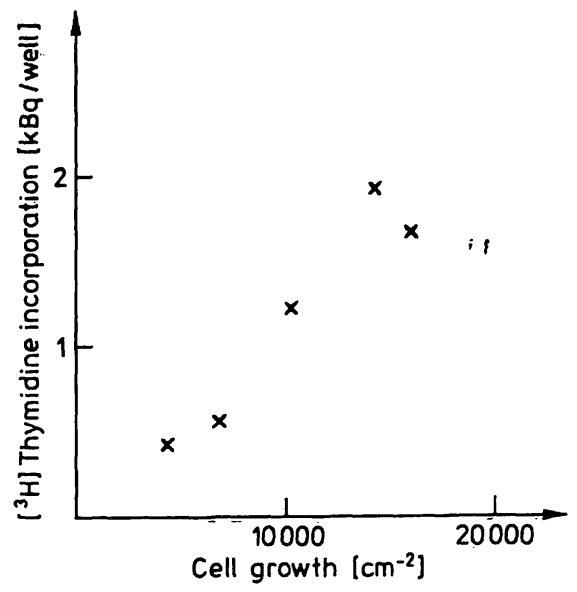

Fig. 4. Correlation of $\left[{ }^{3} \mathrm{H}\right]$ thymidine incorporation and cell growth of human palmar fascia fibroblasts.

$\left[{ }^{3} \mathrm{H}\right]$ thymidine incorporation: in $\mathrm{kBq}$ per culture well (2 $\mathrm{cm}^{2}$ surface; volume fraction of foetal calf serum 0.01 ; cell density 11000 cells $/ \mathrm{cm}^{2}$ ):

Cell growth: Increase of cell number per $\mathrm{cm}^{2}$ culture surface after a $40 \mathrm{~h}$ period.

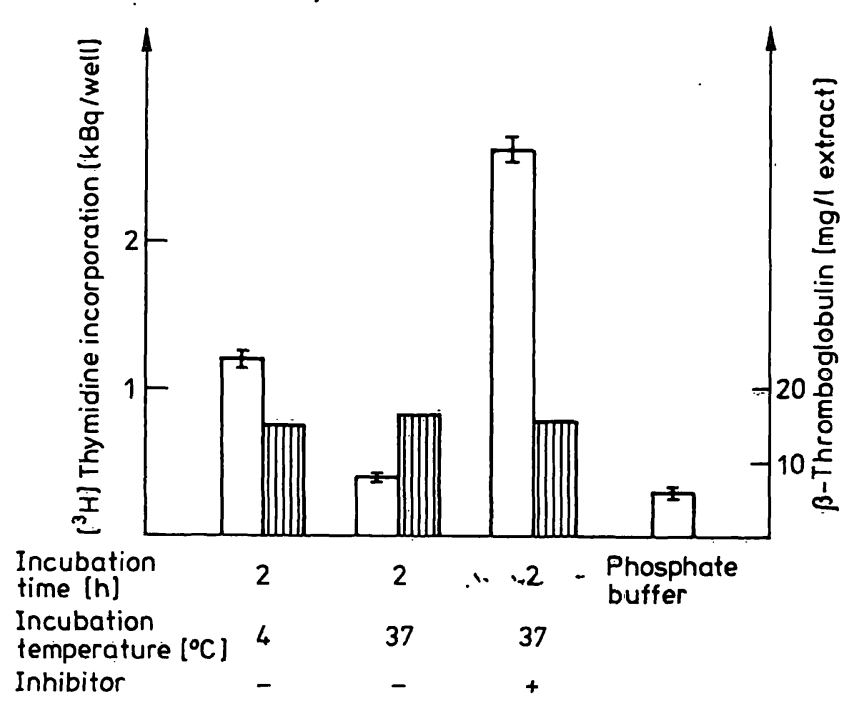

Fig. 5. Proteolysis of platelet growth factor: Incubation of crude platelet extract as indicated, followed by inactivation at $100^{\circ} \mathrm{C}$ for 10 minutes and separation of platelet growth factor by heparin-Sepharose chromatography. Determination of factor activity by proliferation stimulation test. Incorporation in $\mathrm{kBq}$ per culture well $\left(\mathrm{n}=6 ; 2 \mathrm{~cm}^{2}\right.$ surface; cell density 20500 cells $/ \mathrm{cm}^{2}$; volume fraction of foetal calf serum 0.01 ). The bars indicate the standard deviation.

$\square\left[{ }^{3} \mathrm{H}\right]$ thymidine incorporation

in $\beta$-thromboglobulin content

Chromatofocusing of immunologically identical platelet factors was undertaken to separate the substances on the basis of their different isoelectric points. Fractionation into $3 \mathrm{pl}$ ranges A: $>9$ (platelet basic protein), B: 8.9-7.6 (connective tissue activating peptide/low affinity platelet factor 4) and $\mathrm{C}: 7.5-$ 6.5 ( $\beta$-thromboglobulin) yielded a fraction at $\mathrm{pI}>9$ that was also immunologically identical to $\beta$-thromboglobulin. Unlike the other fraçtions, however, it retained mitogenic activity in toto (fig. 6). Its molec- 


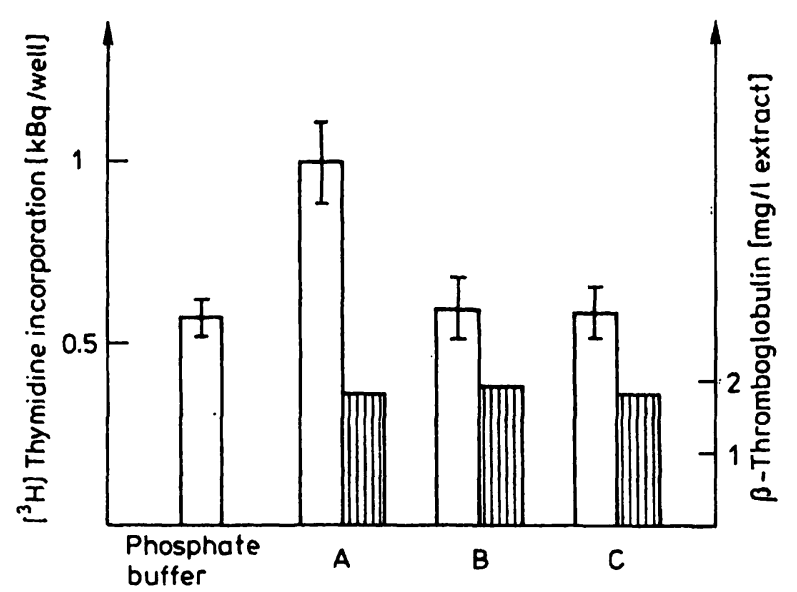

Fig. 6. Fractionation of platelet factors by chromatofocusing on Polybuffer exchanger 94 with Polybuffer 96 (Pharmacia). pI ranges: $\mathrm{A}: \mathrm{pH}>9.0, \mathrm{~B}: \mathrm{pH}$ 8.9-7.6, $\mathrm{C}: \mathrm{pH} 7.5-6.5$ Platelet growth factor activity was determined after rechromatography on heparin-Separose. $\left[{ }^{3} \mathrm{H}\right]$ Thymidine incorporation in $\mathrm{kBq}$ per culture well $\left(\mathrm{n}=6 ; 2 \mathrm{~cm}^{2}\right.$ surface; cell density about 30000 cells $/ \mathrm{cm}^{2}$; volume fraction of foetal calf serum 0.01 ), the bars indicate the standard deviation.

$\square\left[{ }^{3} \mathrm{H}\right]$ thymidine incorporation

Ш $\beta$-thromboglobulin content

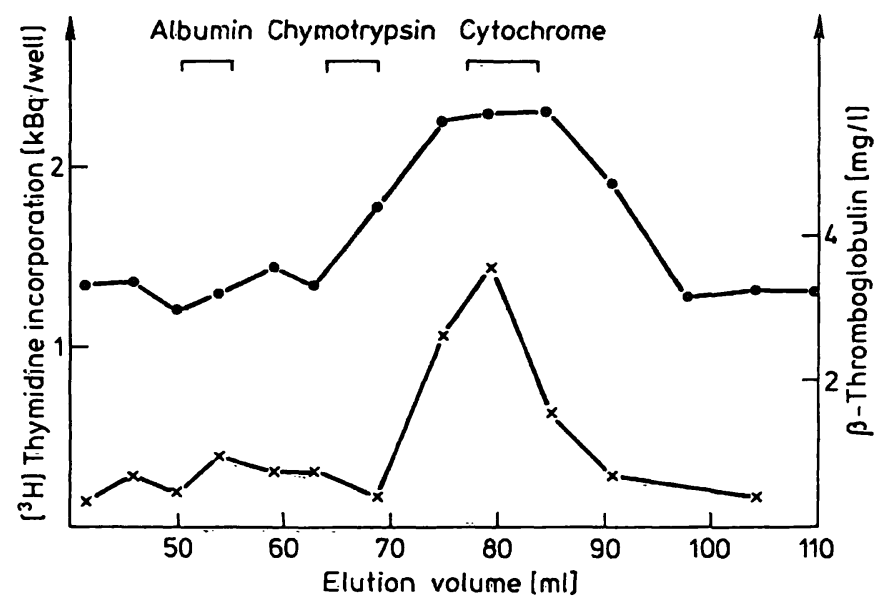

Fig. 7. Stimulation of $\left[{ }^{3} \mathrm{H}\right]$ thymidine incorporation by fractions obtained by Sephadex G 75 chromatography (column: $120 \times 1.5 \mathrm{~cm}$, eluted with Dulbecco's phosphate buffer, $3 \mathrm{ml}$ per hour, $\mathrm{V}_{0}=38.5 \mathrm{ml}$ ) of platelet growth factor previously purified by chromatography on heparin-Sepharose and chromatofocusing. $\left[{ }^{3} \mathrm{H}\right]$ Thymidine incorporation in $\mathrm{kBq}$ per cultture well $\left(\mathrm{n}=6 ; 2 \mathrm{~cm}^{2}\right.$ surface; cell density about 17000 cells $/ \mathrm{cm}^{2}$; volume fraction of foetal calf serum 0.01).

$x=x \quad \beta$-thromboglobulin content

$\left[{ }^{3} \mathrm{H}\right]$ thymidine incorporation

ular mass was determined to be approximately 12500 daltons. The corresponding fraction also proved to be immunologically identical to $\beta$-thromboglobulin after molecular sieve filtration (fig. 7). The determined molecular mass agrees with that described by Paul for platelet basic protein. No proliferation stimulation in the molecular mass range of 27000-35.000 daltons, as reported for platelet-derived growth factor, was observed.

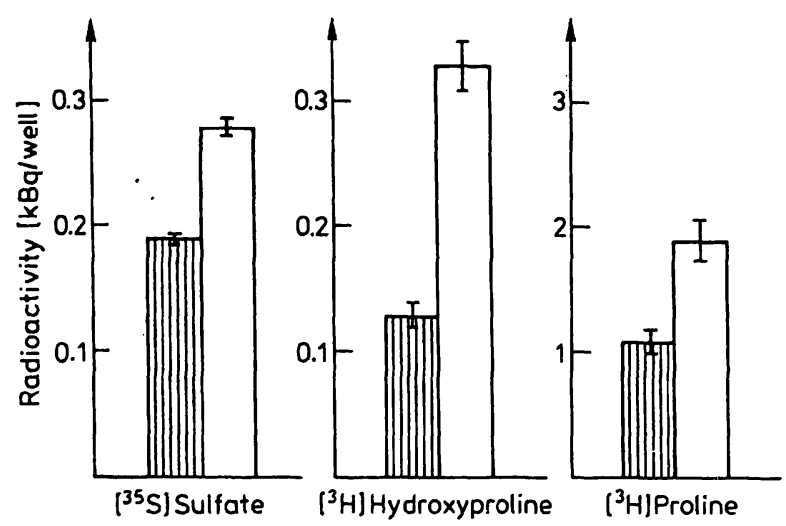

Fig. 8. Effect of purified platelet growth factor on the metabolism of cultured palmar fascia cells. Incorporation in $\mathrm{kBq}$ per culture well ( $\mathrm{n}=4 ; 8 \mathrm{~cm}^{2}$ surface; volume fraction of foetal calf serum 0.01 ; cell density 23100 cells $/ \mathrm{cm}^{2}$ for $\left[{ }^{35} \mathrm{~S}\right]$ sulphate incorporation, $46000 \mathrm{cells} / \mathrm{cm}^{2}$ for $\left[{ }^{3} \mathrm{H}\right]$ proline and $\left[{ }^{3} \mathrm{H}\right]$ hydroxyproline incorporation, respectively). Labeled precursors were added 20 hours after addition of the factor ( $350 \mathrm{ng} \beta$-thromboglobulin immunoreactive material per $\mathrm{ml}$ culture medium). Incorporation time 48 hours. The bars indicate the standard deviation.

mil control: buffer only

$\square$ sample with platelet growth factor

The isolated growth factor exhibited mitogenic properties in the proliferation test. Thus the addition of $350 \mathrm{ng}$ of platelet factor per test preparation leads to about a seven-fold increase in DNA synthesis as compared to the control value. Moreover, the factor also demonstrates an ability, although not as pronounced, to stimulate collagen and glycosaminoglycan metabolism.

As can seen from the results in figure $8,350 \mathrm{ng}$ of platelet factor per test preparation induces an increase in the glycosaminoglycan synthesis rate (measured on the basis of $\left[{ }^{35} \mathrm{~S}\right]$ sulphate incorporation) by a factor of 1.5 , as well as an acceleration in collagen synthesis (measured on the basis of $\left[{ }^{3} \mathrm{H}\right]$ proline and $\left[{ }^{3} \mathrm{H}\right]$ hydroxyproline incorporation) by a factor of 2.5 .

\section{Discussion}

Several authors have described mitogenic factors in platelets that are released during blood coagulation or are poured into the bloodstream from $\alpha$-granula of the platelets in a release reaction. The methods employed to isolate these factors from platelets partly determine the definition and properties of the factors themselves.

As the results show, we were able to demonstrate a mitogenic factor in crude platelet extracts. The factor yields positive results in the $\beta$-thromboglobulin 
radioimmunoassay and exhibits mitogenic activity in the proliferation test. The addition of protease inhibitors was essential for obtaining the mitogenic compound. In the absence of these inhibitors, the factor is degraded by cell or tissue proteases to $\beta$-thromboglobulin, which is inactive as a stimulator. A similar degradation of connective tissue activating peptide III has been discussed by Castor (22). In vivo, especially in plasma, the proteases appear to function by limiting the effect of the platelet growth factor, thereby counteracting any excess release of the factor.

With the aid of chromatofocusing it was possible to separate the growth stimulating fraction from immunologically identical factors on the basis of their different isoelectric points (pI) - platelet basic protein (pI: 10.0), connective tissue activating peptide/low affinity platelet factor 4 (pI: $8.0-8.5$ ) and $\beta$-thromboglobulin (pI; 7.0). It was shown that only the fraction having an isoelectric point of greater than $9 \mathrm{ex}$ hibits mitogenic activity. The fraction containing connective tissue activating peptide III exhibited no activity in the proliferation test; this observation disagrees with the results of Castor. The discrepancy could be accounted for if we assume that the method used by Castor probably did not achieve complete separation of platelet basic protein and connective tissue activating peptide III. A relative molecular mass of about 12500 was determined for the isolated growth factor. At the same time the substance proved to be immunologically identical to $\beta$-thromboglobulin. These results agree with the data published by Paul et al. (14) for the human platelet basic protein.

In the relative molecular mass range of about 30000 , in which platelet derived growth factor (pI: 10.0) was expected, (according to Heldin et al. (23) this factor does not cross-react with $\beta$-thromboglobulin antiserum), we observed no increase in the rate of $\left[{ }^{3} \mathrm{H}\right]$ thymidine incorporation. The reason for this may lie in the substantially lower initial quantities of these substance in the crude platelet extract $(200$ times less), as measured by $\beta$-thromboglobulin immunoreactive material. Further, inactivation of platelet-derived growth factor during the chromatofocusing step must be considered. This, however, requires further investigation.

Besides marked mitogenic properties, the isolated platelet growth factor also stimulated glycosaminoglycan and collagen synthesis. This coincides with the findings of other authors. Thus Burke \& Ross (24) described stimulation of collagen synthesis in monkey smooth muscle cells by platelet growth factor. Castor et al. (25) observed increased release of acidic glycosaminoglycans into the culture medium of human fibroblasts following the addition of platelet factor.

From the above results the following picture emerges. Human platelet basic protein with a relative molecular mass of about 12000 represents the active growth factor from platelets. This compound is degraded by the cleavage of oligopeptides to form connective tissue activating peptide/low affinity platelet factor 4 and then $\beta$-thromboglobulin, with the immunological determinants remaining intact.

The above described proliferation test was based not on the 3T3 mouse cells widely cited in the literature for determination of mitogenic activity, but rather on a homologous system (human fibroblasts/human platelet factor). For improved reproducibility and in order to avoid dedifferentiation phenomena as far as possible, it is advisable to work with only a single cell line in the second to fourth subcultures. There seems to be no need for addition of a 'progression factor' (26). Obviously the calf serum used in the culture media provides sufficient somatomedin activity to enable the fibroblasts to answer the stimulation by the platelet growth factor (competence factor).

In this system the variation coefficient (CV) is less than $10 \%$. Comparisons with experiments using various cell lines are not possible due to the high biological variance involved. Experiments with permanent lines of human fibroblasț às test cells are now in progress.

In addition to the use of the test for characterizing the mitogenic activity of fractions and factors isolated from platelets, the system also permitted the direct assay of the mitogenic activity of factors released from platelets in biological material, following their isolation by heparin-Sepharose chromatography. This is all the more important, as the elevated $\beta$-thromboglobulin levels (plasma/synovia) reported by Mac Carter (8) and Myers \& Christine (9) in rheumatic diseases provide no information on the quantity of active growth factor. The $\beta$-thromboglobulin radioimmunoassay represents only a very sensitive method for detecting enhanced thrombocytic function.

\section{Acknowledgements}

The authors express their gratitude to Miss Ursula Pöhls and Mr. Heinrich Schröder for their skilled technical assistance. 


\section{References}

1. Balk, S. D. (1971) Proc. Natl. Acad. Sci USA 68, 271-275.

2. Scher, C. D., Shepard, R. C., Antoniades, H. N. \& Stiles, C. D. (1979) Biochim. Biophys. Acta 560, 217-241.

3. Busch, C., Wasteson, A. \& Westermark, B. (1976) Thromb. Res. 8, 493-500.

4. Ross, R., Glomset, J., Kariya, B. \& Harker, L. (1974) Proc. Natl. Acad. Sci USA 71, 1207-1210.

5. Golde, D. W. (1980) Anal. Intern. Med. 92, 650-662.

6. Zetter, B. R. \& Antoniades, H. N. (1979) J. Supramolecular Structure 11, 361-370.

7. Heldin, C. H., Westermark, B. \& Westeson, A. (1981) Proc. Natl. Acad. Sci. USA 78, 3664-3668.

8. Mac Carter, D. K., Hossler, P. A. \& Castor, C. W. (1981) Clin. Chim. Acta 115, 125-134.

9. Myers, S. L. \& Christine, T. A. (1982) J. Rheum. 9, 6-12.

10. Weissbarth, E., Limon, W., Eckert, J., Menninger, H. \& Deicher, H. (1981) In: Arthritis - Models and Mechanism. pp. 244-248 (Deicher, H. \& Schulz, L. Cl., eds.), Springer Verlag, Berlin-Heidelberg-New York.

11. Antoniades, H. N., Scher, C. D. \& Stiles, C. D. (1979) Proc. Natl. Acad. Sci. USA 76, 1809-1813.

12. Heldin, C. H., Westermark, B. \& Wasteson, A. (1981) Biochem. J. 193, 907-913.

13. Raines, E. W. \& Ross, R. (1982) J. Biol. Chem. 257, 51545160.

14. Paul, D., Niewiarowski, St., Varma, K. J., Rucinski, B., Rucker, S. \& Lange, E. (1980) Proc. Natl. Acad. Sci. USA 77, 5914-5918.
15. Castor, C. W., Ritchie, I. C., Williams, C. H., Scott, M. E., Whitney, S. L., Myers, S. L., Sloan, T. B. \& Anderson, B. E. (1979) Arthritis Rheum. 22, 260-272.

16. Rucinski, B., Niewiarowski, St., James, P., Walt, D. \& Budzynski, Z. (1979) Blood 53, 47-82.

17. Moore, S. \& Pepper, D. S. (1977) In: Platelets in Biology and Pathology. pp. 293-311 (Gordon, I. L., ed.), North Holland, Amsterdam and London.

18. Delbrück, A. \& Schröder, H. (1983) J. Clin. Chem. Clin. Biochem. 21, 11-17.

19. Dicker, P., Pohjanpelto, P., Pettican, P. \& Rozengurt, E. (1981) Exp. Cell Res. 135, 221-227.

20. Heldin, C. D., Wasteson, A. \& Westermark, B. (1977) Exp. Cell Res. 109, 429-437.

21. Antoniades, H. N. \& Scher, C. D. (1977) Proc. Natl. Acad. Sci. USA 74, 1973-1977.

22. Castor, C. W., Cobel Geard, S. R., Hassler, F. A. \& Kelch, R. P. (1981) J. Clin. Endocrinol. Metab. 52, 128-132.

23. Heldin, C. H., Westermark, B. \& Wasteson, A. (1981) Exp. Cell Res. 136, 255-261.

24. Burke, J. M. \& Ross, R. (1977) Exp. Cell Res. 107, 387395.

25. Castor, C. W., Ritchie, I. C., Scott, M. E. \& Whitney, S. L. (1977) Arthr. Rheum. 20, 859-868.

26. Stiles, C. D., Capone, G. T., Scher, C. D., Antoniades, H. N., Van Wyk, J. J. \& Pledger, W. J. (1979) Proc. Natl. Acad. Sci. USA $76,1279^{\circ}-1283$.

Dr. Bernd Dresow

Institut für Klinische Chemie II

Medizinische Hochschule Hannover

Zentrallabor im Krankenhaus Oststadt

Podbielskistraße 380

D-3000 Hannover 51 
